\title{
The Politics of Anticolonial Resistance: Violence, Nonviolence, and the Erosion of the British Empire
}

\author{
Richard J. McAlexander* \\ Perry World House \\ University of Pennsylvania \\ Philadelphia, PA 19104 \\ richardmcalexander@gmail.com
}

August 19, 2020

\begin{abstract}
This paper studies conflict in a hierarchical international system, the British Empire. How did the British Empire respond to violent and nonviolent resistance within its colonies? I develop a theory explaining how and why the metropole becomes involved in and grants concessions to its colonies. In contrast to more recent work, I find that violence was more effective at coercing metropolitan concessions to the colonies in the British Empire than nonviolence. This theory is supported with a wide range of data, including yearly measures of anticolonial resistance, every colonial concession made by the British Empire after 1918, daily measures of metropolitan discussions of colonial issues from cabinet archives, and web-scraped casualty data from British death records. My findings show that the effectiveness of resistance is conditional on the political structure that it is embedded in and that hierarchy matters for understanding state responses to resistance.
\end{abstract}

Keywords: empires; conflict; decolonization; hierarchy; violence; nonviolence, suffrage. Word count: 10,858

\footnotetext{
* Thanks to Page Fortna, Jack Snyder, Sarah Daly, Michael Doyle, Andreas Wimmer, Matthew Connolly, and Josh Simon for their helpful guidance and feedback on this project.
} 


\section{Introduction}

The fall of the European empires in the 20th century transformed the international system. Explanations in the International Relations literature locate this change by referencing Cold War dynamics or the restructuring of the global economy. Less emphasis is placed on the role of anticolonial resistance within the colonies. This is puzzling, since anticolonial resistance was a near constant response to imperial rule, occupied an important role in metropolitan politics, and shaped colonial policy. Both violent and nonviolent forms of anticolonial resistance mobilized populations all around the globe, and the leaders of these movements at the time of independence came to rule their states for decades. Yet little is known about how the European empires responded to resistance, what the relative effects of violent and nonviolent resistance were, and how resistance in imperial structures may differ from the more commonly studied context of the nation-state.

The standard approach in the IR and conflict literature is to examine resistance and conflict between states in an anarchical international system (interstate war), or within a state in a hierarchical domestic structure (intrastate war) (Waltz, 2010). Despite a burgeoning theoretical and empirical literature on international hierarchy (Mattern and Zarakol, 2016; Lake, 2009a), few works have studied how hierarchical relationships between states in the international system are contested, negotiated, and ultimately severed. Examining the decolonization process and how resistance within the colonies affected metropolitan policy can shed light on conflict dynamics in a hierarchical international structure: the European overseas empires.

This paper studies the effects of violent and nonviolent anticolonial resistance on metropolitan policy in the British Empire during the 20th century. To do this, I present a model of imperial response. Empires, unlike nation-states, are political structures that are segmented into the metropole and its peripheral units. Peripheral units are directly administered by the local governors, but the metropole is in charge of large-scale changes in policy and other imperial relations. Metropolitan involvement in the colonies varies spatially and temporally. I theorize that anticolonial resistance can induce concessions from the metropole when the resistance is better able to command metropolitan involvement. Violent resistance is more effective at coercing metropolitan concessions because it threatens the metropole's core interests and garners the attention of the 
metropole. While disruptive to governance, nonviolent resistance is much less likely to be debated and discussed by metropolitan policymakers. Nonviolence, because it does not threaten the core interests of the metropole, remains the province of the colonial governor.

I test this theory in the context of the largest polity in history, the British Empire (Taagepera, 1978). I collected original data on measures of violent and nonviolent anticolonial resistance in every British colony from 1918 to independence, every concession granted by the metropole to the colony, and daily measures of metropolitan discussion of each colony using British Cabinet archives. In addition, I provide daily casualty data for five colonial conflicts using web-scraped death records of British citizens who were killed in these conflicts to validate the measures of anticolonial resistance.

This paper presents a number of important findings. The main result is that violence is overwhelmingly more effective at coercing concessions from the metropole than nonviolence. In a wide range of statistical models, the effect of nonviolent resistance on a concession is null. Debates in the House of Commons were much more likely to focus on violent than nonviolent anticolonial activity, and cabinet discussions were more likely to discuss colonies experiencing violent, rather than nonviolent, resistance. These concessions were substantially quite important: metropolitan concessions are strong predictors of the suffrage level in each colony.

This paper contributes to the literature on violent and nonviolent resistance. This study has a large scope while simultaneously providing a granular analysis of the effects of resistance by using months or weeks as the unit of analysis. Doing so enables the study of the short-term effects of resistance, which can help alleviate endogeneity concerns. The finding that violence is more effective at coercing concessions is at odds with results from other works examining similar questions within the context of the nation-state (Stephan and Chenoweth, 2008). I argue that the reason for this discrepancy is that the interests of the European colonial overseas empires in general and the British Empire in particular were threatened more by violence than nonviolence. This argument implies that in order to properly assess the effects and success of any type of resistance campaign, the interests - their values and willingness to concede - of the target of a campaign must be understood.

In addition, I build on recent IR work on hierarchy in the international system by providing a theory of imperial response. A large number of works in the political economy and economics 
literature have used fine-grained data to examine the long-term effects of colonial investments on current developmental and political outcomes (Huillery, 2009). The general conclusions from these works are that the decisions made by the colonial powers - on where to invest, who to colonize,

etc. - have long term repercussions. Yet there remains a lack of theorizing about how the empire makes decisions, how colonial subjects can shape policy, and how the unique metropole-periphery structure of imperial rule matters for understanding the dynamics of empires. By presenting a theory of imperial response, I show that the hierarchical structure of an imperial polity matters for understanding how policy within an empire is shaped, and that this may differ from the domestic context of a nation-state.

These findings are also relevant to the debate about the causes of decolonization. Decolonization was "the most important change in word politics" (Jervis, 1989: 34) during the 20th century, but the analyses of causes of this change have been understudied by IR scholars (for an exception, see (Crawford, 2002)). By showing that concessions - which increased suffrage to the colonies and facilitated self-determination - were a response to violent unrest, this work highlights the role that resistance within the colonies played in increasing the level of colonial autonomy. By studying low-level acts of resistance rather than just the maximalist campaigns of Gandhi or the Mau Mau, I am able to show that anticolonial resistance mattered more than previously thought.

\section{Empires, Violence, and Nonviolence}

Empires are a form of international hierarchy (Mattern and Zarakol, 2016; Lake, 2009a). Empires, regardless of how control is acquired, are characterized by a metropole and a periphery (Doyle, 1986; Nexon and Wright, 2007; Wimmer and Min, 2006; Lake, 2009b). This structural division matters for understanding imperial dynamics and metropolitan responses to activity in the periphery. Metropolitan involvement in the periphery varies over time and space and helps explain why some types of resistance are effective at granting concessions. Variation in metropolitan involvement only occurs in the context of an imperial structure and has no clear analogue to the nation-state.

A consequence of the core-periphery structure of an empire is that the metropole can selectively engage and disengage with its peripheral units. This tendency was higher in the modern European overseas empires than in the more traditional land-based empires like the 18th century Russian Em- 
pire (Kumar, 2019: 161). Heterogeneous contracting between the metropole and periphery means that there is variation in autonomy, obligations, and importance across colonies. The metropole can place larger demands on some colonies than others. While many historical accounts acknowledge this variation in the context of France's relationship to West Africa and Algeria (Aldrich, 1996), less is known about what drives temporal variation in metropolitan involvement and attention to its colonies. I argue that metropolitan involvement is both an important characteristic of imperial rule and also helps us understand when the metropole changes its policy towards the periphery.

Despite the centrality of the core-periphery structure as a characteristic of imperial rule, few studies have examined how hierarchical links between states in a core-periphery relationship are contested. Moreover, less is known about how formal hierarchical links break and are replaced by informal ones. One of the characteristics of international hierarchy is some form of compromised sovereignty by the subordinate state. How can the subordinate state restore some of its sovereignty from the dominant state? Why and when does the dominant state devolve power to some peripheries but not others? My key variable that explains this outcomes is violent anticolonial resistance, which disrupts the relations between the metropole and the periphery.

This work builds on existing research on the relative effects of violent and nonviolent resistance. The majority of these works focus more on characteristics of resistance campaigns or the variety of strategies used by those doing the resistance. While government responses are an important outcome variable of these works, very often the interests of the targeted government are left unexplored. The literature on mass violent and nonviolent campaigns, for example, only examines variation in effectiveness against democracies and autocracies (Stephan and Chenoweth, 2008; Griffiths and Wasser, 2018), as does the literature on the effectiveness of terrorism (Pape, 2006; Stanton, 2013; Fortna, 2015). In the civil war and self-determination literature, explanations for why states grant concessions are located in divisions within a movement (Cunningham, 2011) or their short-term use of violence (Thomas, 2014a). In contrast, this work focuses more on the structure of the targeted government and offers a theory designed to explain government responses.

Recent works have assessed the effectiveness of violence and nonviolence by comparing the success rate of maximalist campaigns (Stephan and Chenoweth, 2008; Griffiths and Wasser, 2018). 
This approach suffers from a number of inferential problems, especially when applied to decolonization campaigns. Applying such an approach to the British Empire would not tell us much because decolonization and independence were overdetermined. Indeed, a striking feature of Griffiths and Wasser's data is that all anticolonial secessionist movements - regardless of the methods they useare coded as successful. Similarly, in Stephan and Chenoweth's dataset, all anticolonial campaigns that are active at the time of independence are coded as successful campaigns while those that petered out before independence is declared are deemed unsuccessful campaigns. Furthermore, there are huge inferential problems arising from the endogeneity between British reluctance to grant a colony independence and the likelihood that a violent campaign arises at all or that a nonviolent campaign turns violent. For some colonies, de facto independence occurred well before de jure independence, which placated more aggressive nationalists. Moreover, anticolonial resistance occurred in widely different contexts. The Mau Mau revolt in Kenya, for example, was largely a civil war among the Kikuyu ethnic group that resulted in the deaths of about two dozen settlers (Bennett, 2013; Anderson, 2005). The British spent many lives and resources to combat the Mau Mau rebellion, but in Ceylon, the British were unwilling to pay those costs. Once there was the specter of violence in Ceylon in 1948, the British withdrew (Thomas, 2014b: 110).

\section{Theory of Imperial Response}

This section presents my theory of imperial response. I specify the three key variables in my analysis: anticolonial resistance, concessions, and metropolitan attention.

\subsection{Anticolonial Resistance}

The first variable is anticolonial resistance. I define anticolonial resistance as contentious political actions by colonial subjects that were in any way related to the colonial state. Since my theory is target-centered, and the colonial mindset flattened nationalist and proto-nationalist resistance into criminal unrest and rebellion, I include nationalist and non-nationalist forms of anticolonial resistance in my key independent variable. ${ }^{1}$

The variable of anticolonial resistance is also limited to non-institutional forms of contentious

\footnotetext{
${ }^{1}$ In this sense, my variable is entirely unconcerned with whether an episode of resistance is truly nationalist.
} 
politics. Most colonies possessed some form of representative institutions for colonial subjects. These institutions allowed the native elites to shape policy through conventional means: negotiations, meetings, petitions, etc. Institutional resistance was an important form of colonial politics. However, native elites were also collaborationist. They benefited, sometimes handsomely, from the colonial regime and facilitated the colonial project. Their interactions with the British were not contentious. They were part of, and not separate from, the colonial state. For these reasons, institutional forms of resistance conducted by the native elite are not included in my variable of anticolonial resistance.

This variable includes common and visible forms of resistance such as riots, protests, strikes, boycotts, and bombings. More organized forms of resistance are included as well, such as an armed insurgency, as happened in places like Kenya, Cyprus, and Palestine. Notably, most discussions of anticolonial resistance focus on these types of mass conflicts and counterinsurgency operations, or with Ghandi or Nkrumah's use of nonviolent civil resistance.

My theory explicitly considers the relative effects of violent and nonviolent forms of resistance. The main difference between the two variables here is whether the resistance results in any physical destruction or harm to individuals. Deaths (intentional or not) as a result of an act of resistance will almost always mean that the resistance was violent. Riots, even when no one is physically harmed, are also considered violent because they result in the destruction of property and injuries to bodies. Acts of nonviolent resistance include mass protests, organized boycotts, and strikes. Colonial subjects commonly used strikes to coerce concessions from local industry. In some cases, these strikes were explicitly nationalist. For example, during the war in Cyprus, over 1,000 Cypriots organized a hunger strike to protest British policies (Correspondent, 1957), and in Palestine, the 1936-1939 Arab nationalists successfully orchestrated a general strike for months until it petered out and devolved into a more conventional violent insurgency (Kelly, 2017).

\subsection{Concessions}

The second variable, and my main dependent variable, is a concession from the metropole to a colony. I define a concession as a substantive policy change by the metropole that favored the colony. This definition excludes smaller favorable actions and larger repressive actions. The revocation of 
a constitution or the declaration of an emergency was a substantive policy change, but did not favor the colony. Other colonial acts did favor colonial subjects, for example the reduction of taxes collected or the distribution of investments to specific regions. These types of changes were often made at the local level by colonial or district governors and did not require metropolitan input. In my theoretical model, concessions are enacted by the metropole in order to provide some benefit to the colonies. Concretely, these benefits usually resulted in the granting of rights, increased representation, or increased suffrage. Within the colonial empires, concessions were not a tactic used only by the metropole. Colonial governors and even district governors used concessions as well. However, these were more often smaller concessions that related to the day-to-day governance of a colony, namely tax relief and colonial investments. Local level officials could accede to the demands of colonial subjects by distributing investments or by selectively choosing not to collect legally mandated taxes. This, however, required no change in colonial policy and was determined by local and colonial governors, not metropolitan politicians.

\subsection{Metropolitan Involvement}

In contrast to nation states, the territorial reach of an empire is much larger relative to the extent of metropolitan territorial control. Areas under control of the metropole are much more in flux as well. Territorial gains can come and go in an empire without jeopardizing the fundamental institutional core of the state itself. Britain could lose India and remain Britain, but Spain losing Catalonia would result in a fundamentally different entity. Furthermore, the federal structure of the nation-state is different from the hub-and-spoke structure of imperial systems. Federal nation-states integrate equal units and lack a core (Cooley, 2005: 27). The sheer number of formal colonies and areas with informal territorial control in an imperial system means that metropolitan involvement to each area is not constant. Quite simply, there are times where the metropole can safely ignore some areas at the expense of others.

I argue that metropolitan involvement is the mechanism linking resistance in a colonial territory with any substantive change in metropolitan policy. The hierarchical structure of imperial systems provides local level governors with sufficient powers and resources to run colonies with limited metropolitan intervention and only occasional or regular oversight. Large-scale policy changes 
become more likely when the metropole becomes involved in colonial affairs simply because the metropole controls the resources and means in order to make these changes. When anticolonial resistance occurs in a colony, policymakers in the metropole may discuss the colony more to figure out the proper way to address the colonial unrest. Unrest without involvement does not lead to metropolitan reforms.

How does understanding metropolitan involvement matter for understanding the relative effects of violence and nonviolence on concessions? The answer is that resistance causes concessions via involvement. This happens in two ways: resistance increases the amount of involvement to a colony from the metropole, and resistance also changes the discourse about the colony with in the metropole. The empirical implication here is that when resistance occurs, the metropole will discuss the colony and will do so in different ways depending on whether the resistance is violent or nonviolent. My theory predicts that violence in a colony will lead to increased involvement to that colony relative to nonviolence, while the impact of nonviolent resistance on metropolitan discourse is lower.

\subsection{Hypotheses}

My theory posts that the structure of imperial rule matters for understanding the differential effects of violent and nonviolent resistance. The British Empire commonly granted concessions to its colonies. This is in contrast to federally structured nation-states where segmented states within the federal structure may seek concessions. In those cases, reputational effects and the need to preserve territorial integrity make concessions that increase autonomy to secessionists risky (Walter, 2009). The nature of imperial structures means that concessions can more easily be granted to one colony without substantially encouraging other colonies to demand similar concessions. (The British feared that giving concessions to one African country would inspire demands in a nearby one, but most of the anticipated contagion was for geographically proximate colonies, not all of those within the empire.) In response to violence, then, concessions can be granted without jeopardizing the entirety of imperial rule.

I argue that, unlike federally structured nation-states, the distance (in terms of geographic but also in terms of information and control) between the metropole and its colonies meant that 
policymakers in the metropole were much less frequently concerned with the goings on in each individual colony. Metropolitan attention to colonies was at a premium. In order for subjects to do something that led to a change in policy, they needed to get the attention of the metropole. Since the amount of attention devoted to each colony was low and the default position in most cases was to delegate authority and control to local-level officials, metropolitan policymakers were quite happy to not discuss a colony and let colonial governors administer the colony and perform other, non-imperial tasks.

Resistance had the potential to disrupt this equilibrium. Resistance could overwhelm the capacity of local colonial state to repress, contain, or defuse the resistance. Resistance was also visible to outside and domestic observers. Unrest in the colonies undermined the reputation of the British as benevolent colonial rulers who were shepherding their subjects into the next stage of development. Resistance in the colonies could also inject colonial issues into metropolitan politics. Since resistance signaled that local colonial officials were unable to maintain order in their colonies, the metropole responded by discussing the situation in the colony. For the British Empire, important discussions of colonial unrest occurred in the House of Commons and the Cabinet. Both institutions routinely conversed with local officials in the Colonial and Foreign Offices. It was in these institutions where the appropriate metropolitan response was discussed and debated.

All else equal, metropolitan governments preferred no resistance in their colonies. Resistance inhibited tax collection, the building of the colonial state, the extension of colonial investments, and perhaps most importantly, entangled empires in colonial wars. At the same time, metropoles would prefer not to devote extra-institutional metropolitan attention to colonies. The structure of imperial rule created local governors and colonial officials whose job it was to oversee and administer the colonies. As in any principal-agent relationship, the principal (the metropole) preferred that the agent (colonial officials) do what the principal delegated the agent to do with as minimal oversight and interference as possible. The default state of the metropole was thus to spend as little attention and hope for as little resistance as possible in their colonies.

If the theorized overall effect of resistance is to increase metropolitan attention, why does the difference between violence and nonviolence resistance matter? I argue that violence is effective 
against imperial rule for two reasons. Violence was better able to increase metropolitan attention to the colonies. This attention made it possible for the metropole to respond by offering colonial concessions. Violence is more effective at garnering metropolitan attention because violence made it very difficult to maintain colonial rule. Nonviolent resistance simply did not garner the attention of the metropole because strikes, protests, and boycotts could be easily dealt with using traditional colonial methods of concessions made by the local colonial government. Increasing wages, for one, was a tried and true tactic of officials in colonial Africa. It is not that nonviolent resistance was futile or ineffective - indeed, nonviolent resistance by colonial subjects likely had a serious impact on the development of the colonial state and patterns of taxation and investments. The fiscal state of a colony was, of course, important and affected the lives of colonial subjects. However, the metropole controlled the most important political features of the colonial state: its constitution, level of suffrage, political representation, etc. Nonviolence may grant a wage increase but could not bring about a reformed constitution or self-government.

I use the above theory to generate testable hypotheses. The fundamental difference between violence and nonviolence in my theory, and in most other definitions, is that violence is destructive, either by harming or killing people, or by destroying infrastructure. Nonviolence, however, makes it difficult for the empire to rule its colonies, engage in resource extraction, and maintain international legitimacy. If the metropole is more concerned with the destructive effects of activity by subjects, then we would expect the metropolitan response to this activity to respond with concessions in an attempt to stave off future unrest. If protests, strikes, and boycotts threaten imperial rule, then the metropole should respond to these actions with concessions. This generates Hypotheses 1 and 2 , respectively.

Hypothesis 1 (H1). Violent anticolonial resistance within a colony should lead to concessions by the metropole to the colonial state.

Hypothesis 2 (H2). Nonviolent anticolonial resistance within a colony should lead to concessions by the metropole to the colonial state.

Before the metropole responds to unrest with concessions metropolitan policymakers must discuss the colony in order to formulate a policy. The effectiveness of a type of resistance can in part 
be assessed by its ability to garner metropolitan involvement. My theory predicts that violence will have a positive effect on metropolitan involvement because violence directly threatens the core interest of the metropole, whereas nonviolent activity can safely be handled by the local colonial government. This theory generates hypotheses 3 and 4 .

Hypothesis 3 (H3). Violent anticolonial resistance should increase metropolitan involvement to a colony.

Hypothesis 4 (H4). Nonviolent anticolonial resistance should increase metropolitan involvement to a colony.

\section{Resistance \& Concessions in the British Empire}

I test this theory in the context of the British Empire. Not all colonies were equally important to those in London. For example, India was the "Jewel in the Crown" of the British Empire, while much smaller island colonies rarely received any involvement from London. Geostrategic dynamics altered the value of colonial possessions over time. The postwar anxiety over declining sterling reserves raised the importance of some colonies (Krozewski, 2001). British interests in Malaya grew rapidly after the loss of India due to Britain's need to convert sterling into dollars and rising great power rivalry in the region (Stockwell, 1995: liv). Maintaining rule over Malaya became essential during the sterling crises since the large volume of rubber exports from Malaya enabled the easy exchange of dollars into sterling (Hinds, 1999: 107). The Cold War also changed the value of colonies. Foreign Secretary Ernest Bevin argued in the immediate postwar period that Britain must maintain control of all their Middle Eastern territories in order to prevent Soviet encroachment (Heinlein, 2013: 15-16).

Some colonies were viewed as strategically essential for the defense of the empire. The British fought to maintain control of Cyprus largely because the loss of India and Palestine reduced their strategic foothold in the Middle East. Withdrawal from Cyprus would result in immediate unification with Greece and the decline in British influence in the region (Heinlein, 2013: 57). Similarly, Palestine's importance was primarily strategic since it provided easy access to British military bases in Egypt and India (Fieldhouse et al., 2006: 196,218). Aden was viewed by The Committee of Im- 
perial Defense as a colony of "general strategic importance to the empire" because of its wireless telegraph and fueling station (Hankey, 1996: 47).

Throughout the 20th century the British Empire routinely granted concessions to the colonies. The main reason these concessions occurred was due to unrest within the colonies (Smith, 1978). Concessions were either a response to past unrest or an attempt to stave off future unrest (Rathbone, 1992: xxxvii). In the era of anticolonial nationalism, colonial officials engaged in a policy of "making reasonable concessions [to the colonies] without conceding any points which are genuinely essential" (Heinlein, 2013: 24). The goal was the gradual advance to self-government and the empowerment of native elites that ensured favorable relations with Britain in the post-independence period. For example, in 1946 the Governor of Burma quickly conceded demands to the Anti-Fascist PFL in order to defuse the situation after a series of strikes threatened to paralyze the colony (Heinlein, 2013: 43). During the late 1940s, the strategy of granting concessions to quell unrest was also used in Malaya alongside conventional counterinsurgency tactics (Heinlein, 2013: 52).

London granted concessions to the colonies mostly by reforming the constitution or expanding the legislative council. Constitutional reforms often expanded suffrage, increased internal selfgovernment, and established institutions with native control. Expanding the legislative council (the primary legislative body within a colony) was an easy concession to make that increased local representation without requiring the process of a constitutional amendment. In the vast majority of cases, the seats added to the legislative council were seats earmarked to be held by native, and not European, elites. This helped dilute the power of the European seats. In theory and in practice, expanding the legislative council increased the representation pf the non-European population.

While the Colonial Office was mostly in charge of implementing concessions, they did so under metropolitan pressure. For example, Howard Johnson argues that the Colonial Office focused their involvement on the implementation of labor legislation reforms in the wake of the West Indian disturbances of 1937-1938 due to criticism from the Labour Party in Parliament (Brown and Louis, 1999: 608). Lord Moyne, then the Secretary of State for the Colonies, in 1941 proposed a constitutional reform for Jamaica and an increase in suffrage to the Jamaican Governor (Wallace, 1977: 56). For the reform of the Gold Coast constitution in 1954, the Colonial Office drafted 
recommendations which were then formally accepted by those in Whitehall (Rathbone, 1992: lx). In 1950 the Secretary of State for the Colonies appointed a board to review the constitutions of British colonies in the Caribbean (Wallace, 1977: 75). Ultimately the decision to grant independence was a metropolitan one. Before Ceylon became fully self-governing, the House of Commons passed the Ceylon Independence Bill in November of 1947 (Heinlein, 2013: 50).

Indeed, selective metropolitan involvement was baked into British rule. Colonial governors ruled over district administrators, and London was quite happy to let the agent in the principle-agent relationship rule the colony without unnecessary interference. In some sense, metropolitan involvement to a colony was a failure of local colonial governing. There were regularly scheduled avenues for metropolitan oversight of the colonies. Territories administered by the Colonial Office were subject to Question Time in Parliament. The production of annual reports-collected for posterity in the appropriate nicknamed 'Blue Books'-occupied substantial resources of colonial officials and the numbers contained in these reports captured enormous detail about colonial happenings. For example, if the metropole cared to know about how many pairs of socks Iraq exported to Palestine in 1937-including whether the socks were made out of plain cotton yarn mixed with shoddy of wool and cotton or plain cotton yard mixed with artificial silk - they could consult the Blue Books. The relevant point here is that metropolitan involvement to each one of of its colonies by the cabinet and parliament was outside of regularly scheduled channels.

\section{Research Design}

To test my theory, I run a number of statistical models to analyze the relationship between variables. Since concessions were relatively infrequent events that were not immediate reactions to anticolonial resistance, I use colony-years as the unit of analysis when the dependent variable is whether a colony receives a concession from the metropole. However, metropolitan attention was more frequent and also responded quicker to events in the colonies. For this reason, and to limit the threat of unobserved heterogeneity that may bias my inferences, I use a colony-month as the unit of analysis when estimating the effect of unrest on metropolitan attention. Since the choice to use violence or nonviolence by imperial subjects was a strategic one, it is unlikely that there exists a scenario where there is as-if random variation in violence and nonviolence, and it is even more 
unlikely that such a design examining this hypothetical scenario would have any meaningful external validity. Using a granular unit of analysis such as the colony-month (while not equivalent to complete randomization of the independent variables) aids inference by ensuring that similar units of analysis are being compared. Furthermore, the private nature of metropolitan discussion as measured by cabinet archives helps limit reverse causality as one potential threat to inference. While endogeneity is present in nearly all observational studies - and especially those involving the dissolution of centuries-old international phenomena involving dozens of countries around the globe - this approach helps increase the likelihood that the effects uncovered in the statistical models reflect a causal relationship.

Temporally, my study is limited to the so-called 'Second' British Empire, which began after World War I (Parsons, 2014). I chose this cutoff for three reasons. One is that there is better quantitative and qualitative data available after World War I. The other is that, after the fall of the Ottomans, the British acquired some of its former possessions, including Palestine. These territories were the last important colonies acquired by the British Empire, which simplifies the analysis by not having units enter into the sample. Colonies are removed from the sample after they are formally granted independence. The third, and perhaps most important reason for this temporal cutoff, is that this time period is commonly believe to be one where the British Empire started declining (Hyam, 2007). This is important for understanding the scope conditions of my theory. Concessions must be a reasonable policy option; in the era of imperial expansion, the usual response to unrest was the consolidation of imperial rule, not retrenchment (Gopal, 2019). I include territories formally administered by the Colonial Office and the India Office, and exclude the Dominions, since there was almost no variation in either the independent or dependent variable. ${ }^{2}$

\section{Data}

Instead of relying on hand-coded measures of violence and nonviolence, I perform a textual search of the entire Times of London newspaper corpus. This results in a more granular independence

\footnotetext{
${ }^{2}$ The obvious exception to a Dominion that experienced resistance is Ireland. Given Ireland's proximity and geographic contiguity with the United Kingdom, it is excluded from the sample. The colonies in the study are: Aden, Barbados, Bechuanaland, British Guiana, Burma, Ceylon, Cyprus, Gambia, Gold Coast, India, Jamaica, Kenya, Malaya, Malta, Nigeria, Northern Rhodesia, Nyasaland, Palestine, Sudan, Southern Rhodesia, Tanganyika, Trinidad, and Uganda.
} 
variable that also includes smaller-scale acts of resistance. I construct this data by executing a query on the Gale Historical Newspapers Database. First, I select all news articles where the colony name is in the subject or keyword of the article in the Times. Then, I filter the articles to ones that include words from a selected list that refer to violent and nonviolent activity. ${ }^{3}$ I then sum the number of articles containing each word for every year. This results in two colony-year variables measuring violent and nonviolent activity in the colonies. The data are presented in Figure 1.
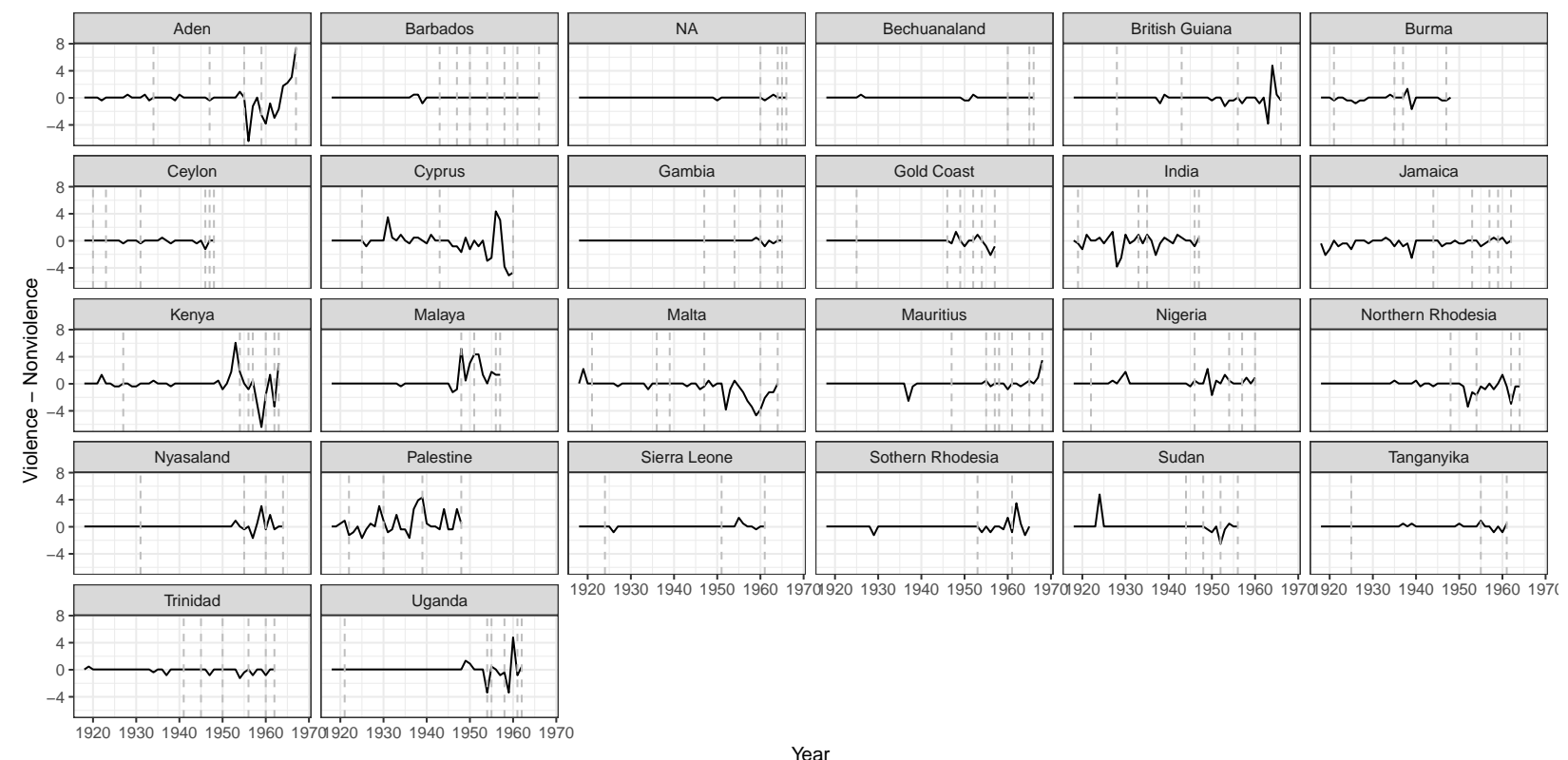

Figure 1: This plot shows the yearly level of violent relative to nonviolent activity in the colonies. Vertical lines indicate years in which a concession was granted.

The dependent variable in my study is whether the colonial government grants a concession to those in the colony. To reiterate, I define a concession as any formal substantive change in colonial policy that favored colonial subjects. In almost all cases, a concession was a reform that devolved autonomy, usually through increased representation, to colonial subjects. Data on concessions were hand-coded at the year level through examining historical dictionaries, encyclopedias, and the vast secondary literature on British imperialism. The variable used in the analysis is simply a binary

\footnotetext{
${ }^{3}$ Words related to nonviolence are: boycott, protest and strike. Words related to violence are: terrorism, riots and insurgency. In choosing these words, the main goal was to use words that would be more likely to describe actions by the colonized rather than the colonizer. For example, "massacre" or "atrocity" could refer to colonial or anticolonial activity. Words with a pejorative meaning would be more likely to be applied to activity by the colonized. To avoid ambiguity about whether the act is violent or nonviolent, common words like "unrest", "disturbance", and "revolt" were excluded.
} 
variable indicating if a concession was granted in that year. In addition, I also use a ordinal measure of concessions. This variable ranges from 0-3 and rates constitutional changes (coded as 3 ) as being larger concessions than those related to expanding the legislative council (coded as 2). All other concessions are coded 1, and these include policies such as recognizing a nationalist leadership in a constitutional conference, facilitating self-government at the local level, or other policies.

I also use a number of time-varying controls. To control for the level of repression in a colony, I use two measures. One is the government censorship effort, which captures the government's attempt to censor print or broadcast media. Censorship was a common tactic by the British to repress nationalist dissent in the colonies. The other variable is the physical violence index. This measures the freedom from political killings and torture by the government. Repression can affect the prevalence of different types of resistance and may also affect the rate of concessions. Other controls intended to capture variation in the political and economic development of a colony include the number of political parties that have national organizations, whether a political party has unified control over the government, the distribution of power across social groups, the suffrage level, the urbanization rate, and educational equality. These measures come from Varieties of Democracy dataset (Coppedge and Ziblatt, 2018).

To construct a measure of metropolitan attention by the cabinet, I use the cabinet archives containing the conclusions of each cabinet meeting during the time period studied. These documents contain brief information on each cabinet meeting, including what issues were discussed and the conclusions reached. An example document is presented in Section A4 in the appendix. The prime minister had discretion over the topics discussed at a cabinet meetings, while the departmental ministers could request an issue for discussion. These documents were circulated to all those present at the meeting, and on occasion the Cabinet Secretary would send them to the heads of the Treasury, Foreign Office and Chiefs of Staff (Thurston, 1998). For each document, I note what colonies were discussed and the date of the discussion. ${ }^{4}$ Since the data are right-skewed, I take the $\log$ of the total discussions. These data are presented in Figure 2.

\footnotetext{
${ }^{4}$ The reference groups for these documents is: CAB 23, CAB 24, CAB 65, CAB 66, CAB 67, CAB 68, CAB 128, CAB 129, CAB 181, and CAB 195.
} 


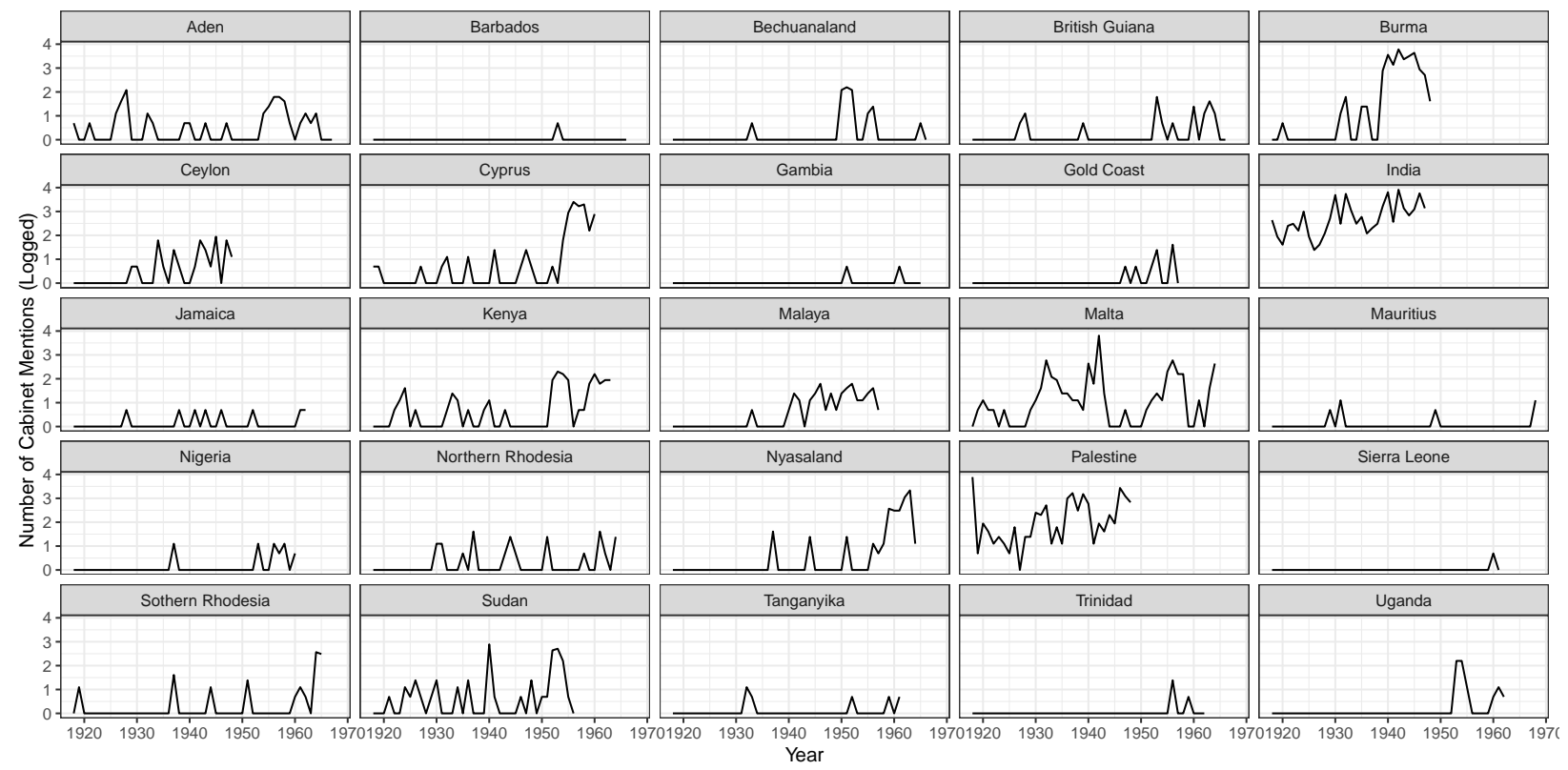

Figure 2: This plot shows the log of the number of times per year that each colony is discussed by the British Cabinet.

\section{Model, Estimation and Results}

To estimate the effects of my independent variables on my dependent variables, I begin by estimating a number of models with the following baseline form:

$$
\text { Concession }_{i_{t}}=\alpha+\beta_{1} \text { Violence }_{i, t-1}+\beta_{2} \text { Nonviolence }_{i, t-1}+\zeta \boldsymbol{X}_{\boldsymbol{i}, \boldsymbol{t}-\mathbf{1}}+\epsilon_{i}
$$

Where $\boldsymbol{X}$ is a matrix of control variables and $\zeta$ is a corresponding vector of coefficients. The main parameters of interest are $\beta_{1}$ and $\beta_{2}$, which represent the marginal effect of an increase in violence and nonviolence in the previous year on a concession, respectively. Violence and nonviolence are lagged one year because concessions required metropolitan deliberation and the formation of policy, and were rarely granted immediately after resistance occurred. Standard errors are clustered at the colony.

I begin by estimating four models: a logit model, a normal linear model with colony fixed effects where the dependent variable is a binary indicator for whether any concession occurred, a normal 
linear model with an ordinal dependent variable measuring the size of a concession, and an ordinal logit model with the same dependent variable. Later, I estimate a Bayesian hierarchical model with observations grouped by the colony to account for dependence between observations within a colony and to explore heterogeneous effects. Whenever the dependent variable is a concession, cubic time splines are included to control for temporal dependence (Carter and Signorino, 2010). The unit of analysis for all models is the colony-year. Additional specifications are provided in the appendix.

These results are presented in Table 1. Across models, specifications, and measures of the dependent variable, violence is a statistically significant positive predictor of a concession, while nonviolence is not.

\begin{tabular}{lcccc}
\hline \hline & \multicolumn{3}{c}{ Dependent variable: } \\
\cline { 2 - 5 } & \multicolumn{2}{c}{ Concession (Binary) } & Concession (Ordered) & Concession (Ordered) \\
& $(1)$ & $(2)$ & $(3)$ & $(4)$ \\
\hline Violence & $0.411^{* *}$ & $0.065^{* * *}$ & $0.139^{* * *}$ & $0.424^{* *}$ \\
& $(0.179)$ & $(0.022)$ & $(0.052)$ & $(0.165)$ \\
Nonviolence & -0.049 & 0.007 & 0.008 & -0.034 \\
& $(0.173)$ & $(0.020)$ & $(0.048)$ & $(0.163)$ \\
Physical Violence Index & $0.801^{*}$ & $0.763^{* * *}$ & $1.929^{* * *}$ & $0.803^{* * *}$ \\
& $(0.483)$ & $(0.214)$ & $(0.510)$ & $(0.012)$ \\
Freedom of Expression & 0.002 & $0.075^{*}$ & $0.175^{*}$ & 0.030 \\
& $(0.109)$ & $(0.042)$ & $(0.100)$ & $0.096)$ \\
Educational Equality & 0.057 & $0.074^{* * *}$ & $0.182^{* * *}$ & 0.016 \\
& $(0.112)$ & $(0.027)$ & $(0.064)$ & $0.112)$ \\
\hline Model & Logit & OLS & OLS & Ordered Logit \\
Observations & 1,106 & 1,106 & 1,106 & 1,106 \\
$\mathrm{R}^{2}$ & & 0.100 & 0.089 & \\
\hline \hline Note: & & & & ${ }^{*} \mathrm{p}<0.1 ;{ }^{* *} \mathrm{p}<0.05 ;{ }^{* * *} \mathrm{p}<0.01$
\end{tabular}

Table 1: This table shows the results of logit, OLS, and ordered logit models where the dependent variable captures whether a colony receives a concession, and its size. The main independent variables measure the level of violence and nonviolence in the colony. Standard errors are clustered at the colony.

To understand the size of the effect of violence on a concession, Figure 3 presents the predicted probabilites for Model 1 in Table 1. 


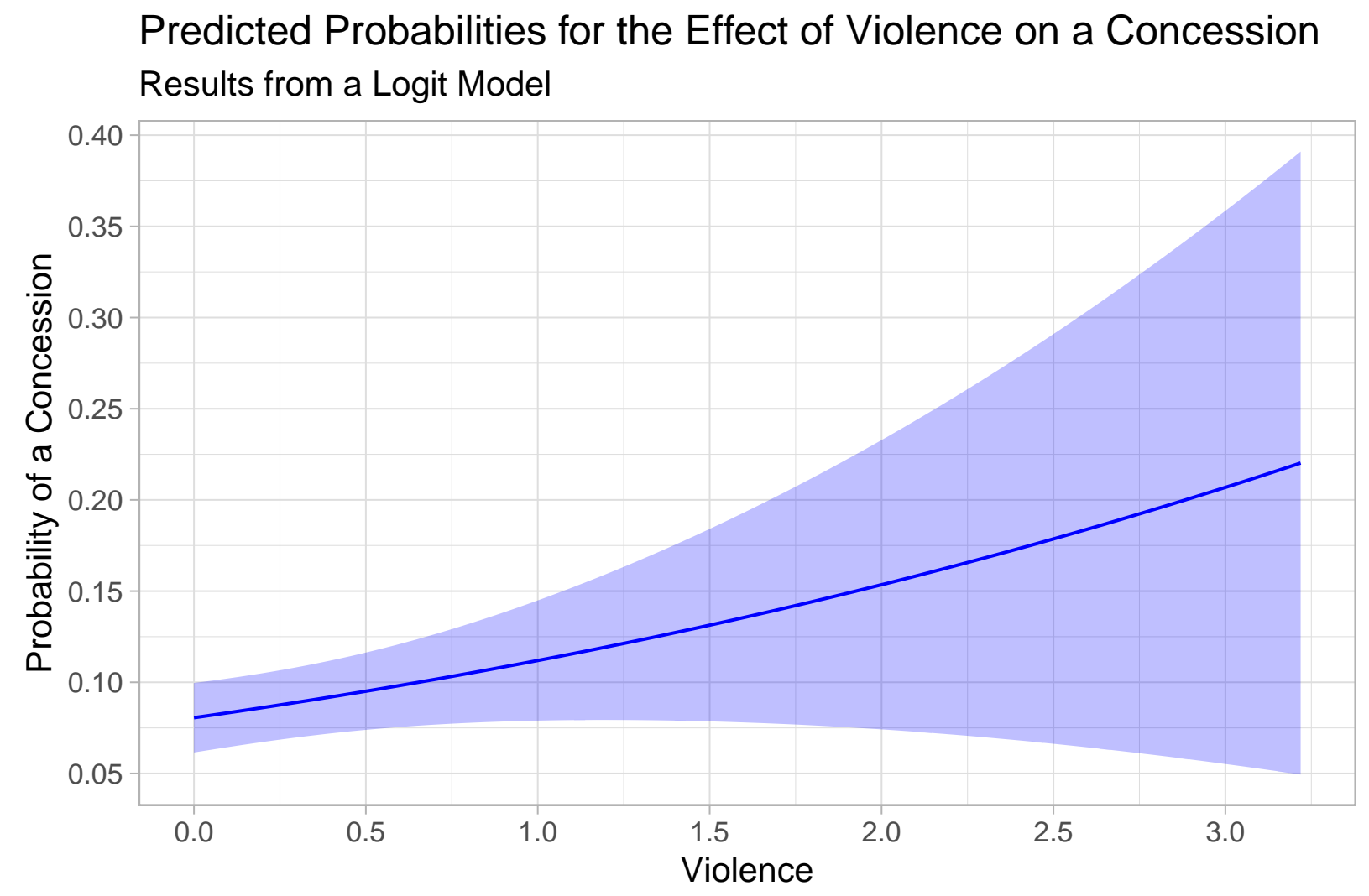

Figure 3: This plot shows the probability of a concession occurring in the following year as a function of violence. When violence is low, there is about a $7.5 \%$ chance of a concession occurring. When violence increases from 0 to 2 , the chance of a concession doubles.

My specified theoretical mechanism linking resistance to concessions is metropolitan involvement. The theorized causal process is that resistance in the colonies leads the metropole to discuss events in those colonies, and when the metropole is more likely to discuss colonial issues, they are more likely to respond to this issues with concessions. This also enables the analysis of data that is more fine-grained than the colony-year.

Table 2 shows the results of models estimating the effect of violence and nonviolence on the amount of discussion of that colony by the cabinet. Both the independent and dependent variables are logged to account for skewness. The unit of analysis is the colony-month. The results show that violence in the previous month predicts the level of cabinet discussion in the subsequent month, while no such effect is present for nonviolence. This pattern holds when the variable measuring levels of violence and nonviolence are lagged by two months. Year fixed effects ensure that the 
comparisons are made within the same year.

\begin{tabular}{|c|c|c|}
\hline & \multicolumn{2}{|c|}{ Dependent variable: } \\
\hline & \multicolumn{2}{|c|}{ Cabinet Discussion } \\
\hline & $(1)$ & $(2)$ \\
\hline Violence (t-1) & $\begin{array}{c}0.188^{* * *} \\
(0.055)\end{array}$ & $\begin{array}{c}0.157^{* * *} \\
(0.040)\end{array}$ \\
\hline Nonviolence (t-1) & $\begin{array}{c}0.094 \\
(0.069)\end{array}$ & $\begin{array}{c}0.071 \\
(0.050)\end{array}$ \\
\hline Violence (t-2) & & $\begin{array}{l}0.072^{* *} \\
(0.032)\end{array}$ \\
\hline Nonviolence (t-2) & & $\begin{array}{c}0.075 \\
(0.065)\end{array}$ \\
\hline Observations & 13,286 & 13,262 \\
\hline $\mathrm{R}^{2}$ & 0.130 & 0.138 \\
\hline Adjusted $\mathrm{R}^{2}$ & 0.124 & 0.132 \\
\hline Residual Std. Error & $0.172(\mathrm{df}=13198)$ & $0.171(\mathrm{df}=13172)$ \\
\hline
\end{tabular}

Table 2: This table shows the results of models where the independent variables are measures of violent and nonviolent activity within a colony and the dependent variable is the level of discussion in the British Cabinet about the colony. The unit of analysis is the colony-month. Measures of activity are lagged by one (t-1) and two (t-2) months. Both models include colony and year fixed effects with standard errors clustered at the colony.

To provide evidence for the link between metropolitan involvement to a concession, I run models where the main independent variable is the level of cabinet discussion about a colony and the dependent variable is whether there is a concession in the following year. Table 3 presents the results. Models 1 and 2 use the binary measure of concessions as the dependent variable, while models 3 and 4 use the ordered measure. The results show that increased discussion by the cabinet leads to a higher probability of concessions.

Additional results are presented in the appendix. In Section A2, I explore how the effect of resistance changes over time. Those results show that the effect of violent resistance increases 
steadily over time. To ensure the robustness of the results, I also estimate models using alternate measures of violent and nonviolent resistance using the House of Commons debates, and find similar effects of resistance on concessions. Those results are presented in Section A1.

\begin{tabular}{|c|c|c|c|c|}
\hline & \multicolumn{4}{|c|}{ Dependent variable: } \\
\hline & \multicolumn{2}{|c|}{ Concession } & \multicolumn{2}{|c|}{ Concesssion (Weighted) } \\
\hline & $(1)$ & $(2)$ & (3) & $(4)$ \\
\hline Cabinet Discussion & $\begin{array}{l}0.039^{* *} \\
(0.017)\end{array}$ & $\begin{array}{l}0.042^{* *} \\
(0.017)\end{array}$ & $\begin{array}{c}0.108^{* * *} \\
(0.040)\end{array}$ & $\begin{array}{c}0.119^{* * *} \\
(0.040)\end{array}$ \\
\hline Physical Violence Index & & $\begin{array}{c}0.570^{* * *} \\
(0.218)\end{array}$ & & $\begin{array}{c}1.683^{* * *} \\
(0.508)\end{array}$ \\
\hline Freedom of Expression & & $\begin{array}{c}0.042 \\
(0.042)\end{array}$ & & $\begin{array}{c}0.057 \\
(0.097)\end{array}$ \\
\hline Educational Equality & & $\begin{array}{c}0.014 \\
(0.030)\end{array}$ & & $\begin{array}{c}0.022 \\
(0.070)\end{array}$ \\
\hline Suffrage Level & & $\begin{array}{l}-0.0003 \\
(0.0005)\end{array}$ & & $\begin{array}{l}-0.001 \\
(0.001)\end{array}$ \\
\hline Observations & 1,106 & 1,100 & 1,106 & 1,100 \\
\hline $\mathrm{R}^{2}$ & 0.190 & 0.202 & 0.206 & 0.222 \\
\hline Adjusted $\mathrm{R}^{2}$ & 0.132 & 0.139 & 0.148 & 0.161 \\
\hline Residual Std. Error & $0.293(\mathrm{df}=1030)$ & $0.290(\mathrm{df}=1019)$ & $0.689(\mathrm{df}=1030)$ & $0.677(\mathrm{df}=1019)$ \\
\hline
\end{tabular}

Note:

${ }^{*} \mathrm{p}<0.1 ;{ }^{* *} \mathrm{p}<0.05 ;{ }^{* * *} \mathrm{p}<0.01$

Table 3: This table presents the results of linear models where the dependent variable captures a concession and the independent variable is the level of cabinet discussion of a colony in the British metropole. The goal here is to assess how increasing metropolitan involvement in colonial politics leads to a increased probability of a concession. Standard errors are clustered at the colony.

\subsection{Exploring Heterogeneity Across Colonies}

Britain's relationship to its colonies varied. To explore the heterogeneity in the effect of violence on a concession, I estimate a Bayesian hierarchical logit model where the independent variables are allowed to vary by colony. This also accounts for within-colony dependence between observations, rather than treat each observation independently. The main parameters of interest is the general and colony-specific effects of violence on a concession. These parameters are jointly estimated, with the population parameter being an mixture of all the colony-specific parameters. The results of 
this model are presented in Figure 4.

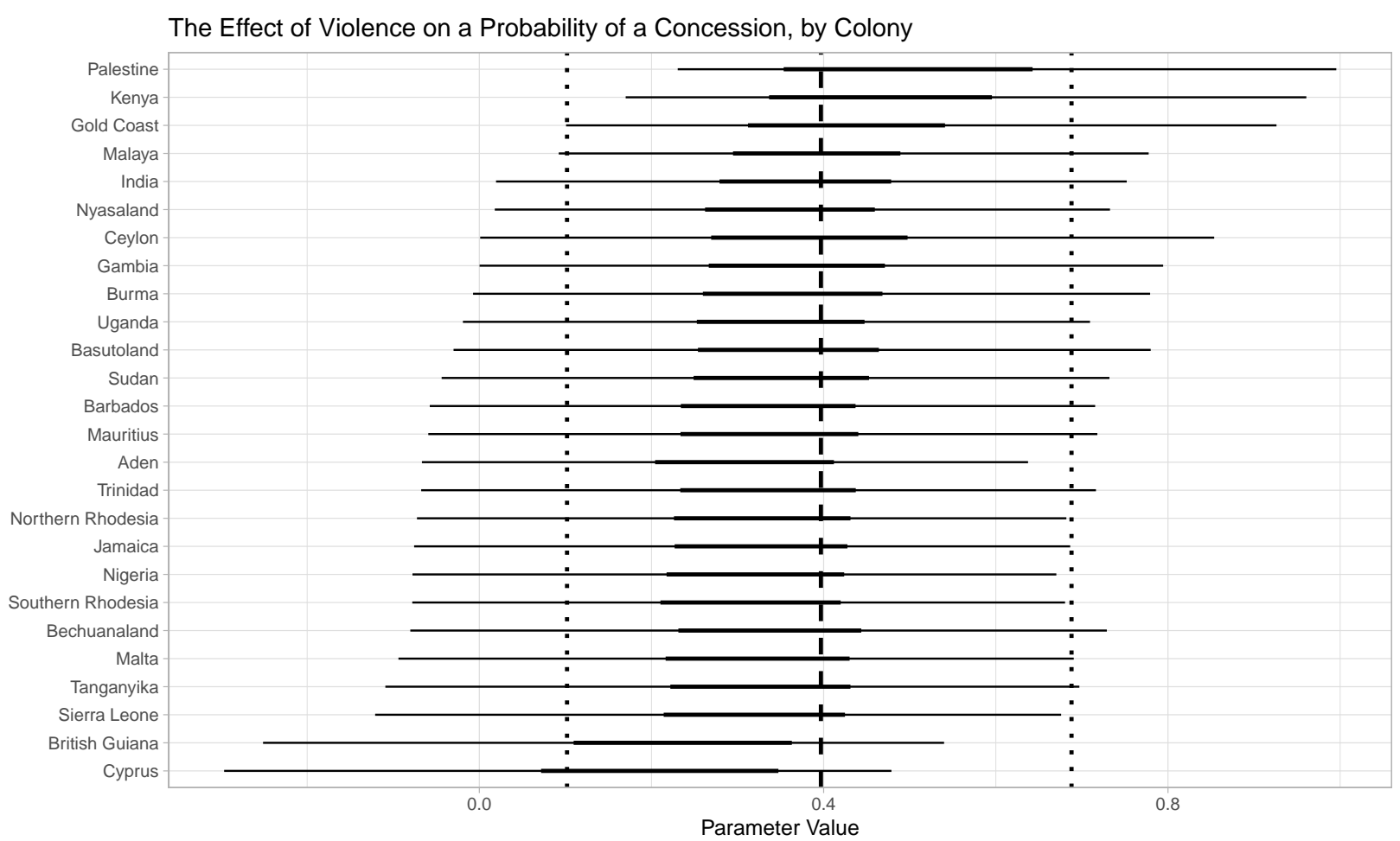

Figure 4: This caterpillar plot shows the results of a Bayesian hierarchical logit model where the observations are clustered within each colony. The plot shows the colony-specific coefficient estimate of the effect of violence on a concession. The horizontal bold line indicates the $50 \%$ posterior density interval while the thinner line indicates the $95 \%$ posterior density interval. We see that violence was most effective in Palestine, Kenya, and the Gold Coast, while violence had little effect in Cyprus and British Guiana.

The left-hand side lists the colonies in deceasing order of the parameter values, with Palestine at the top, indicating that violence in Palestine predicted a concession more than in any other colony. At the bottom is Cyprus. The dashed vertical line indicates the mode of the posterior distribution of the population level effect of violence on a concession, while the dotted lines indicate the $95 \%$ bounds of the posterior interval. These effects are in line with the frequentist logit models estimated in Table 1.

These results show that there was important heterogeneity in the effects of violence on concessions, especially for colonies that experienced a sustained violent conflict, like Cyprus and Palestine. These findings are consistent with the historiographical literature detailing Britain's hasty abandon- 
ment of Palestine in the face of a violent insurgency (Hoffman, 2016) and Britain's unwillingness to grant concessions in the face of violence in Cyprus due to the island's perceived strategic importance (Rappas, 2014).

\section{Robustness Checks}

\subsection{Measurement Error Models}

The data used to construct the measures of anticolonial resistance rely on newspaper reporting. This creates a number of biases that may affect the inferences made from the statistical models. This is a common problem. More contemporary event data using newspaper reports often suffers from undercounting bias. In other words, there are events that occur that do not get reported on, and thus never enter into the datasets used by researchers. Not all events that do not get reported are the same. A mass demonstration with tens of thousands of participants will likely get some coverage, but more routine and smaller events will get ignored.

One of the advantages of using newspaper data is that the biases are generally well known. This enables the use of statistical models that account for these different biases and to see how the main effect behaves as these biases change. Standard regression models assume that there is no measurement error in the independent variable. This is almost always a naive assumption. In this section, I present the results of Bayesian measurement error models that relax this assumption in ways that account for the likely biases of newspaper reporting about the British Empire.

Bayesian measurement error models replace variables where no data exists with probability distributions. The most basic measurement error model replaces the mismeasured independent variable with a normally distributed variable centered around the true value with some added noise. Equation 2 presents this formally:

$$
X_{\text {meas }} \rightarrow \mathcal{N}\left(X_{\text {real }}, \sigma^{2}\right)
$$

This simple model can be extended to account for more complex bias patterns. For the current application, research on reporting bias sheds light on the type of bias present in the models. The most probable source of bias is differential reporting of violent and nonviolent resistance. This bias 
occurs when nonviolent resistance is more likely to be underreport and ignored by the Times of London than violent resistance.

I create a Bayesian measurement error model that accounts for underreporting and estimate it using the Stan language (Stan Development Team, 2018). The code for the model is included in Section A5. I first examine how the general tendency to underreport nonviolence more than violence affects affects parameter estimates in the baseline logit model. ${ }^{5}$ To do this, I introduce an additional parameter into the measurement error model in Equation 2, $\gamma$, which represents the degree of undercounting the true distribution of resistance.

$$
X_{\text {meas }} \rightarrow \mathcal{N}\left(\gamma X_{\text {real }}, \sigma^{2}\right)
$$

When $\gamma=1$, there is no underreporting, and when $\gamma=0$, underreporting is so severe that no events get recorded at all. When $\gamma=0.5$, half the true events are reported and entered into the dataset. The parameter $\sigma^{2}$, is the standard deviation of the measurement model. This can more intuitively be interpreted as "random noise". I set this at 0.125 . I then vary the value of $\gamma$ to see how the parameter estimates change for different levels of undercounting.

The estimated effect of violent and nonviolent resistance at different values of $\gamma$ are presented in Figure 5. The x-axis is the, or $\gamma$. When $\gamma$ is one, there is no undercounting. An interesting exercise is to examine the relative parameter values across different values of $\gamma$ for each independent variable. For example, the effect of violent resistance on a concession is about 1.125 when $\gamma=0.50$, which is still higher than the effect of nonviolent resistance when there is no undercounting at all $(\gamma=1.0)$. This provides evidence that different rates of undercounting the different independent variables are not driving the main results.

\footnotetext{
${ }^{5}$ To facilitate the distribution of the posterior distribution, I scale and standardize all variables.
} 


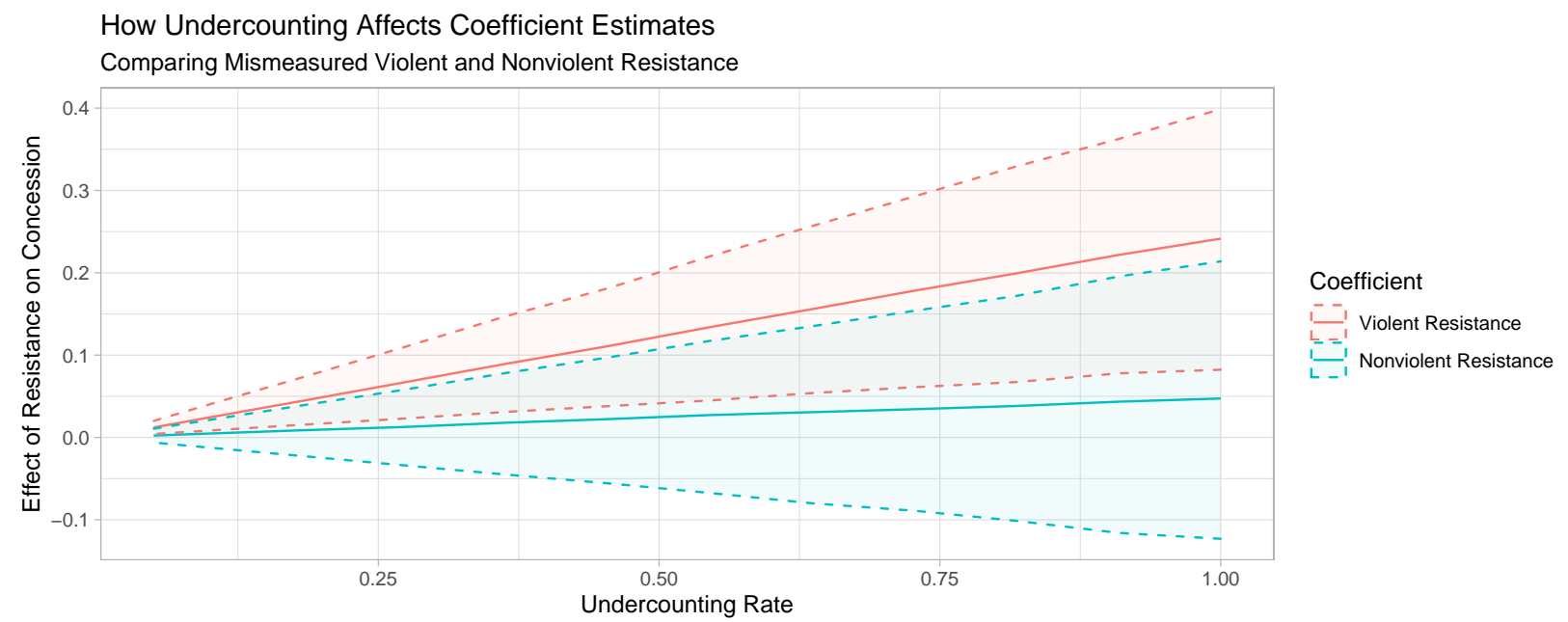

Figure 5: The plot shows how the coefficient for violent and nonviolent resistance changes as a function of the undercounting rate parameter $\gamma$. The shaded area indicates the $95 \%$ posterior density interval. When $\gamma$ is 1 , there is no undercounting and when $\gamma$ is 0 no acts of resistance get reported at all. The effect of both violence and nonviolence on a concession attenuates as undercounting increases. Violence has a positive effect on a concession even if half of the violent events that occur enter into the dataset.

Bias driven by newspaper reporting likely varies across colonies and time. In times when there is more interest in the events of a colony, measurement error should decrease. To account for this, I create a colony-year measurement of newspaper coverage using the Times of London database. This is created by performing a search of all newspaper articles with the colony name listed as a keyword and then extracting the number of news articles with that keyword per year. I then scale this measure to make it range from 0 to 1 . This data is then multiplied by the discount rate, $\gamma$. In effect this means that $\gamma$ varies by the colony-year, and undercounting is higher when there is lower newspaper reporting. I then estimate this model with varying values for $\sigma^{2}$ to see how the parameter values change when $\gamma$ is driven by colony-year variation in newspaper reporting and to see how increased random measurement error affects the estimate of the effect of violence on a concession.

The results are presented in Figure 6. As $\sigma^{2}$ increases, the uncertainty bands increase as well along with the effect size. This is as expected, since measurement error induces attenuation bias. The main takeaway is that even if random measurement error is quite high, and even if the tendency to undercount violence varies from year-to-year in each colony as newspaper coverage increases, the 
effect of violence on a concession remains positive and statistically distinguishable from zero.

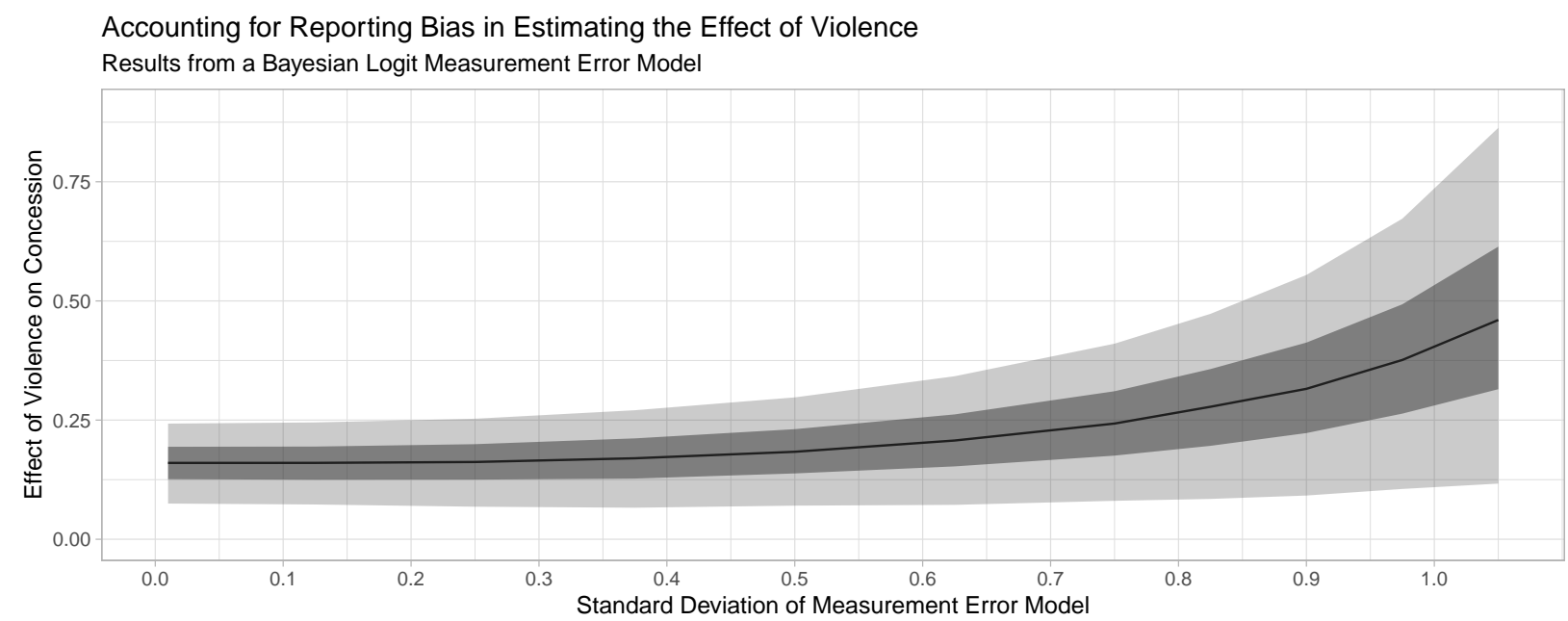

Figure 6: This plot shows the posterior distribution of the coefficient for the effect of violent resistance on a concession in a Bayesian logit measurement error model. The light shaded area indicates the $95 \%$ posterior density interval while the darker shaded area indicates the $50 \%$ posterior density interval. The measurement error varies at the colony-year with the number of newspaper reports of a colony by the Times of London. More newspaper reports capture lower measurement error. The $\mathrm{x}$-axis indicates the standard deviation of the measurement error (akin to 'random noise'). Accounting for varying newspaper coverage, the effect of violence on a concession remains positive and statistically distinguishable from zero.

\subsection{Verification with Casualty Data}

To further support my claim that the newspaper data accurately reflects the level of violence and nonviolence in a colony, I validate these measures with administrative data on British casualties during five colonial conflicts. ${ }^{6}$ To gather this data, I collected the date of every British military casualty that occurred in these colonies from the start of the conflict until independence was declared. This was performed by web-scraping the death records of databases colonial deaths from https://www.findmypast.co.uk/. I scraped the name of each individual casualty in each conflict, extracted the date of their death, and aggregated each death to the year level to create a dataset on the number of casualties in each year for each colony.

The casualty data is not affected by reporting bias at all since it is collected from administrative records. This enables us to validate the measures of violence and nonviolence driven by newspaper

\footnotetext{
${ }^{6}$ These are Cyprus, Palestine, Malaya, Kenya, and Aden.
} 
reporting. If the casualty data are correlated with the measures of violence, and not correlated with the measures of nonviolence, then this should increase confidence in the data and resulting model estimates. There are two important qualifications. The first is that the data do not measure the same underlying concept. Violent anticolonial resistance includes acts that result in property damage and deaths of settlers, British colonial officials who are not members of the military, and deaths of other native colonial officials. The British casualty data includes all military servicemen who die while serving abroad - including those who die of disease or accidentally (automobile accidents were quite common). The relevant point here is that if both data sources are completely free of error, we should not expect a perfect correlation between the two. The second important qualification is that the casualty data is only collected for a small number of colony-years (49) for colonies where the British were engaged in an active counterinsurgency campaign. The dynamics of violence in colonial counterinsurgency campaigns may very well be different in different time periods and different forms of colonial rule.

The measure of British casualties and the measure of anticolonial violence have a correlation coefficient of 0.64 . The casualty measure and nonviolent resistance are negatively correlated at -0.12. Regressing violence and nonviolence on the casualty variables further shows that violence and casualties rates are positively correlated, while nonviolence and casualty rates are not. The result of these models are presented in Table 4. 


\begin{tabular}{lcc}
\hline \hline & \multicolumn{2}{c}{ Dependent variable: } \\
\cline { 2 - 3 } & Violence & Nonviolence \\
& $(1)$ & $(2)$ \\
\hline Casualties & $0.580^{* * *}$ & $-0.281^{* * *}$ \\
Nonviolence & $(0.058)$ & $(0.091)$ \\
Violence & $0.514^{* * *}$ & \\
& $(0.143)$ & \\
\hline Observations & & $0.458^{* * *}$ \\
$\mathrm{R}^{2}$ & 49 & $(0.127)$ \\
F Statistic $(\mathrm{df}=6 ; 42)$ & $23.150^{* * *}$ & 49 \\
\hline \hline Note: & ${ }^{*} \mathrm{p}<0.1 ;{ }^{* *} \mathrm{p}<0.05 ;{ }^{* * *} \mathrm{p}<0.01$
\end{tabular}

Table 4: This table shows the marginal effect of an increase in a British casualty during a colonial conflict on the measure of anticolonial violence coded from newspapers. Because they are rightskewed, all measures are logged. Colony fixed effects are included. Higher casualties are positively associated with the measure on violence and slightly negatively associated with the measure on nonviolence. This provides evidence that the newspaper data is able to discriminate between anticolonial violence and nonviolence.

\section{Conclusion}

I have argued that violent resistance in the British colonies during the 20th century encouraged the colonial state to grant concessions to the colonies. The results here show that violence is more effective at resisting imperialism. There is a consistent null effect of nonviolent resistance on the probability of a metropolitan concession to a colony. The mechanism linking resistance to concessions is metropolitan discussion and involvement, which reacted more to violent resistance than nonviolent resistance.

My theoretical framework attempts to make sense of how the British Empire actually functioned, and how activity in the colonies led to metropolitan involvement. Understanding metropolitan involvement is important because the metropole was in charge of concessions that reformed the constitution or increased native representation. Smaller-scale concessions, such as wage increases or tax relief, remained the province of the colonial governor. Overseas empires have a common structure where local officials manage the day-to-day operations of the colonies and metropolitan involvement in local governance varies spatially and temporally. This matters for understanding 
how and when resistance by colonial subjects shapes policy.

What are the scope conditions of this theory? To answer this question it is important to decouple the dynamics of imperial expansion and contraction (Abernethy, 2000). Briefly, this theory only applies to an era of imperial decline. That is, when imperial retrenchment and withdrawal are realistic policy options and the goal of metropolitan policymakers is to reduce their colonial commitments. When empires are seeking to expand, anticolonial resistance can be used a pretext to more aggressive repression and the formalization of control over colonial subjects. This pattern occurred in the British Empire during the 19th century after the Morant Bay uprising in Jamaica and the Indian Mutiny. In both cases, these rebellions resulted in significant metropolitan discussion (Gopal, 2019). Metropolitan policy, however, did not result in concessions, but resulted in making Jamaica a Crown Colony and assuming control from the British East India company.

While the focus has been on the British Empire, similar dynamics apply to other imperial projects. In the French Empire, nonviolence was often futile. When the Algerians practiced nonviolence, the French responded with repression (Clayton, 2014). Violence both threatened the core interests of the French in Algeria and catapulted the FLN onto the world stage (Connelly, 2002). France's interest in sub-Saharan Africa was much lower and they were more willing to grant autonomy to these colonies than in North Africa (Chafer, 2002). Not all empires shared a clear division between the metropole and periphery as there was in the modern European overseas empires. The land-based Russian Empire, for example, lacked any clear metropole and the various nationalities in the periphery made up the ruling class (Kumar, 2019).

This study has a number of limitations that can be addressed in future work. The data on violent and nonviolent resistance is culled from British newspapers. One advantage of this approach is that it ensures that the metropole is aware, or at least could be aware of unrest within the colonies. In addition, data on unrest from colonial archives would suffer from other reporting biases since many reports containing information on resistance were compiled by subordinates and sent up the chain of command. Too much reported unrest suggests a poor performing colonial official. Of course, not every act of resistance was covered in the press. Many of the foreign correspondents were located in the colony's capital or other large cities. Presumably, acts of resistance in the hinterlands were less 
likely to be reported by these correspondents, thus making it less likely for these acts to be discussed by the metropole and to have a meaningful effect on policy. A full model of what types of unrest were reported by the press and by colonial officials could significantly advance our understanding of when resistance is effective and the inner workings of colonial empires.

The finding that violence was more effective than nonviolence at coercing concessions raises important implications for understanding the fall of the European empires during the 20th century. Explanations abound for the global transition from empire to the nation (Emerson, 1962). Much of this work has focused on variation in the timing of independence for colonies within and across empires (Spruyt, 2005). This work shows that the transition from colony to nation was not a rupture in hierarchical relations between states, rather it was a process where autonomy was slowly granted in response to violence. For many British colonies, independence was a formality, although this applies less to colonies engaged in a sustained campaign against colonial rule. The results here suggest that decolonization spanned the 20th century, accelerated after the end of World War II, and that violent anticolonial resistance played an important role in the decolonization process. The effectiveness of violence was not driven by the more commonly studied large-scale colonial conflicts, rather, concessions were also a response to low-level riots and unrest.

What can this study tell us about contemporary hierarchical relations between states? With few exceptions, however, formal imperial ties are nonexistent in contemporary international politics. Nevertheless there are similarities between a metropole's selective involvement in its formal colonies and great power intervention in its informal client states after the stability of local rule in the client state becomes threatened. In addition, this study shows that Britain successfully managed its imperial decline and avoided large-scale costly conflicts when it made piecemeal concessions to colonial subjects, which has important implications for the literature on great power retrenchment (MacDonald and Parent, 2018). 


\section{References}

Abernethy, David B. 2000. The dynamics of global dominance: European overseas empires, 14151980. Yale University Press.

Aldrich, Robert. 1996. Greater France: A history of French overseas expansion. Macmillan International Higher Education.

Anderson, David. 2005. Histories of the Hanged: the Dirty War in Kenya and the End of Empire. WW Norton \& Company.

Bennett, Huw. 2013. Fighting the Mau Mau: The British Army and Counter-Insurgency in the Kenya Emergency. Cambridge University Press.

Brown, Judith M. and Wm. Roger Louis, eds. 1999. The Oxford History of the British Empire: The Twentieth Century. Vol. 4 Oxford University Press.

Carter, David B and Curtis S Signorino. 2010. "Back to the future: Modeling time dependence in binary data." Political Analysis 18(3):271-292.

Chafer, Tony. 2002. The end of empire in French West Africa: France's successful decolonization. Bloomsbury Publishing.

Clayton, Anthony. 2014. The wars of French decolonization. Routledge.

Connelly, Matthew. 2002. A diplomatic revolution: Algeria's fight for independence and the origins of the post-cold war era. Oxford University Press on Demand.

Cooley, Alexander. 2005. Logics of hierarchy: The organization of empires, states, and military occupation. Cornell University Press.

Coppedge, Michael, John Gerring Carl Henrik Knutsen Staffan I. Lindberg Svend-Erik Skaaning Jan Teorell David Altman Michael Bernhard M. Steven Fish Agnes Cornell Sirianne Dahlum Haakon Gjerløw Adam Glynn Allen Hicken Joshua Krusell Anna Lührmann Kyle L. Marquardt 
Kelly McMann Valeriya Mechkova Juraj Medzihorsky Moa Olin Pamela Paxton Daniel Pemstein Josefine Pernes Johannes von Römer Brigitte Seim Rachel Sigman Jeffrey Staton Natalia Stepanova Aksel Sundström Eitan Tzelgov Yi-ting Wang Tore Wig Steven Wilson and Daniel Ziblatt. 2018. "V-Dem [Country-Year/Country-Date] Dataset v8.".

URL: https://doi.org/10.23696/vdemcy18

Correspondent, From Our. 1957. "1,000 Cypriots On Hunger Strike.” The Times of London p. 10.

Crawford, Neta. 2002. Argument and change in world politics: ethics, decolonization, and humanitarian intervention. Vol. 81 Cambridge University Press.

Cunningham, Kathleen Gallagher. 2011. "Divide and conquer or divide and concede: How do states respond to internally divided separatists?" American Political Science Review 105(2):275-297.

Doyle, Michael W. 1986. Empires. Cornell University Press.

Emerson, Rupert. 1962. From empire to nation: The rise to self-assertion of Asian and African peoples. Beacon Press.

Fieldhouse, David Kenneth et al. 2006. Western imperialism in the Middle East 1914-1958. Oxford university press.

Fortna, Virginia Page. 2015. "Do Terrorists Win? Rebels' Use of Terrorism and Civil War Outcomes." International Organization 69(03):519-556.

Gopal, Priyamvada. 2019. Insurgent Empire: Anticolonial Resistance and British Dissent. Verso Books.

Griffiths, Ryan D. and Louis M. Wasser. 2018. "Does Violent Secessionism Work?" Journal of Conflict Resolution p. 002200271878303.

Hankey, M. 1996. Summary on defence policy: memorandum by Sir M Hankey (CAB 63/38, MO (26)1, ff 3-7, 18-41. Jan 1926. In Imperial Policy and Colonial Practice 1925-1945, ed. S.R. Ashton and S.E. Stockwell. Vol. 1 of Series A Institute of Commonwealth Studies chapter 2, pp. 41-58. 
Heinlein, Frank. 2013. British Government Policy and Decolonisation, 1945-63: Scrutinising the Official Mind. Routledge.

Hinds, Allister. 1999. "Sterling and Decolonization in the British Empire, 1945-1958." Social and Economic Studies pp. 97-116.

Hoffman, Bruce. 2016. Anonymous soldiers: The struggle for Israel, 1917-1947. Vintage.

Huillery, Elise. 2009. "History matters: The long-term impact of colonial public investments in French West Africa." American economic journal: applied economics 1(2):176-215.

Hyam, Ronald. 2007. Britain's declining empire: the road to decolonisation, 1918-1968. Cambridge University Press.

Jervis, Robert. 1989. The meaning of the nuclear revolution: Statecraft and the prospect of Armageddon. Cornell University Press.

Kelly, Matthew Kraig. 2017. The Crime of Nationalism: Britain, Palestine, and Nation-Building on the Fringe of Empire. Univ of California Press.

Krozewski, Gerold. 2001. Money and the End of Empire: British international economic policy and the colonies, 1947-58. Springer.

Kumar, Krishan. 2019. Visions of empire: How five imperial regimes shaped the world. Princeton University Press.

Lake, David A. 2009a. Hierarchy in international relations. Cornell University Press.

Lake, David A. 2009b. "Hobbesian hierarchy: the political economy of political organization." Annual Review of Political Science 12:263-283.

MacDonald, Paul K and Joseph M Parent. 2018. Twilight of the titans: Great power decline and retrenchment. Cornell University Press.

Mattern, Janice Bially and Ayşe Zarakol. 2016. "Hierarchies in world politics." International Organization 70(3):623-654. 
Nexon, Daniel H and Thomas Wright. 2007. "What's at stake in the American empire debate." American Political Science Review 101(2):253-271.

Pape, Robert Anthony. 2006. Dying to win: The strategic logic of suicide terrorism. Random House Incorporated.

Parsons, Timothy H. 2014. The Second British Empire: In the Crucible of the Twentieth Century. Rowman \& Littlefield.

Rappas, Alexis. 2014. Cyprus in the 1930s: British Colonial Rule and the Roots of the Cyprus Conflict. Vol. 66 IB Tauris.

Rathbone, Richard. 1992. "British documents on the end of empire, Series B, vol. 1. Ghana, Part I, 1941-1952.”.

Smith, Tony. 1978. "A comparative study of French and British decolonization." Comparative Studies in Society and History 20(1):70-102.

Spruyt, Hendrik. 2005. Ending empire: Contested sovereignty and territorial partition. Cornell University Press.

Stan Development Team. 2018. "RStan: the R interface to Stan.". R package version 2.17.3.

URL: http://mc-stan.org/

Stanton, Jessica A. 2013. "Terrorism in the context of civil war." The Journal of Politics 75(4):10091022.

Stephan, Maria J and Erica Chenoweth. 2008. "Why civil resistance works: The strategic logic of nonviolent conflict." International security 33(1):7-44.

Stockwell, Allen J. 1995. "British documents on the end of empire, Series B, vol. 3. Malaya, Part I: The Malayan Union Experiment, 1942-1948.".

Taagepera, Rein. 1978. "Size and duration of empires: systematics of size." Social Science Research $7(2): 108-127$. 
Thomas, Jakana. 2014a. "Rewarding Bad Behavior: How Governments Respond to Terrorism in Civil War." American Journal of Political Science 58(4):804-818.

Thomas, Martin. 2014b. Fight or flight: Britain, France, and their roads from empire. Oxford University Press.

Thurston, Anne. 1998. "British documents on the end of Empire. Series C, vol. 2. Records of the Cabinet, Foreign Office, Treasury and other Records.”.

Wallace, Elisabeth. 1977. The British Caribbean from the decline of colonialism to the end of federation. University of Toronto Press.

Walter, Barbara F. 2009. Reputation and civil war: Why separatist conflicts are so violent. Cambridge University Press.

Waltz, Kenneth N. 2010. Theory of international politics. Waveland Press.

Wimmer, Andreas and Brian Min. 2006. "From empire to nation-state: Explaining wars in the modern world, 1816-2001." American Sociological Review 71(6):867-897. 